В. А. Городецька

\title{
ПОРІВНЯННЯ ЯК ОЗНАКА ХУДОЖНЬОГО ІДОЛЕКТУ (НА МАТЕРІАЛІ ПОЕТИЧНОГО МОВЛЕННЯ В. СТУСА)
}

Городецька В. А. Порівняння як ознака художнього ідіолекту (на матеріалі поетичного мовлення В. Стуса).

Статтю присвячено дослідженню порівнянь як специфічної ознаки художнього мовлення В. Стуса на матеріалі збірки поезій «Палімпсести». 3'ясовано, що індивідуально-авторська мовна картина світу репрезентує життя ключовими концептами, які виявляються через систему порівнянь та відкривають підсвідомість художника слова, що бачить буденну реальність в неповторних образах, вмотивованих історією, літературою, релігією, національною культурою загалом. Доведено, що ці складові світобачення поета набувають символічного звучання, розподіляють життя для нього на світ і темряву, спокій і боротьбу, рідне й чуже, відчуття теплих спогадів минулого та повної безвиході сьогодення й майбутнього. Декодовано символічний зміст основних архетипів культурологічного контексту творів автора.

Ключові слова: антропологічна лінгвістика, лінгвокультурологія, порівняння, індивідуально-авторська мовна картина світу.

() В. А. Городецька, 2018. 
Городецкая В. А. Сравнение как особенность художественного идиолекта (на материале поэтической речи В. Стуса).

Статья посвящена исследованию сравнений как специфической особенности художественной речи В. Стуса на материале сборника поэзий «Палимпсесты». Выяснено, что индивидуально-авторская языковая картина мира представляет жизнь ключевыми концептами, которые выявляются через систему сравнений и открывают подсознание художника слова, который видит будничную реальность в неповторимых образах, мотивированных историей, литературой, религией, национальной культурой в целом. Доказывается, что эти составляющие мировосприятия поэта приобретают символическое звучание, распределяют жизнь для него на свет и темноту, спокойствие и борьбу, родное и чужое, ощущение теплых воспоминаний прошлого и полной безысходности настоящего и будущего. Декодируется символическое содержание основных архетипов культурологического контекста произведений автора.

Ключевые слова: антропологическая лингвистика, лингвокультурология, сравнение, индивидуально-авторская языковая картина мира.

Gorodetskaya V. A. Comparison as a Sign of Artistic Idiolect (Basing on Material of Stus' Poetic Language).

The article studies the comparisons as a specific feature of Stus' artistic language in collection of poems "Palimpsests". It has been defined that the author's individual linguistic worldview represents key life concepts through comparisons and opens the subliminal words of the artist, who sees everyday reality in unique images, motivated history, literature, religion, national culture as a whole. These components become symbolic for the poet and guides his perception of life between light and darkness, peace and war, native and foreign, a feeling of the warm memories of the past and a feeling of despair related to the present and future. The article highlights the decoded symbolic meaning of basic archetypes of cultural context in the author's works. The comparisons are divided into three groups: 1) comparisons of mother, wife, son, Ukraine, Kyiv with the world of unforgettable memories of a happy life; 2) comparisons of wall, a prisoner's solitude, the northern landscape (the horizon, dawn, the moon, the sun, peace, prison cell, etc) as a terrible world of hopelessness; 3) comparing the indestructibility of the fighter's soul to supreme justice. The author of the article discovers hidden textual comparisons both in texts of the poems and in the title of their collection as well as literary allusions, for example, "A Word about Igor's Regiment" and Shevchenko's works.

Key words: anthropological linguistics, linguistics, comparison, individual author's language worldview. 
Лінгвістичне дослідження текстів художньої літератури спрямоване на наукову інтерпретацію авторської мовної картини світу. 3 огляду на це перспективним напрямом українського мовознавства залишається дослідження художніх ідіолектів письменників, які виражають індивідуально-авторську модель світу зі всією системою морально-етичних цінностей, світовідчуттям конкретного письменника.

Порівняння $\epsilon$ основою $\mathrm{i}$ водночас засобом пізнання навколишнього реального й уявного світу, яке формується завдяки виявленню подібностей i відмінностей між компонентами дійсності. Будучи основною мисленнєвою операцією, порівняння нероздільно пов'язане 3 діяльністю суб'єкта пізнання, тобто завжди супроводжується спостереженням, а більш детально сприйманням. Зіставлення різних видів об’єктів, їх властивостей або якихось дій передусім служить їх увиразненню, більш повній як якісній, так і кількісній характеристиці, а також виявленню відношень між об'єктами, що порівнюються, та творенню думок.

Порівняння, яке $є$ основною й універсальною мисленнєвою операцією і тим самим пов'язане з мовною діяльністю людини, що знаходить своє віддзеркалення в мовних одиницях, становить один i3 проявів асоціативного мислення. Отож, асоціація, яка $\epsilon$ психічним феноменом, виконує важливу функцію у сприйманні світу і становить вмотивований попереднім досвідом зв'язок, завдяки якому спостереження або ж уявлення, які постали у свідомості, викликають інші уявлення на основі подібності, дотичності (прилеглості) або на основі відмінності рис. Розуміння порівняння як мисленнєвої операції завжди визначене об’єктивними властивостями предметів та явищ, а також наявними між ними відношеннями. Порівняння як урахування подібностей i відмінностей речей $\epsilon$ елементарною розумовою дією щодо встановлення зв'язків між явищами. Порівняння, уміщене в конкретних лексемах, а тому усталене в системних одиницях, має статичний характер.

() В. А. Городецька, 2018. 
Поетичний простір поета Василя Стуса значною мірою орієнтований на страшний час української історії та на світовідчуття його покоління. Ключовою мовною фігурою творів поета $є$ порівняння, за допомогою якого передається поетичне світобачення автора, створюється його ідіостиль.

Індивідуально-авторська мовна картина світу В. Стуса репрезентує навколишню дійсність через ключові концепти, що через систему порівнянь відкривають підсвідомість людинимитця, який бачить буденну реальність в неповторних образах, умотивованих історією, літературою, релігією, національною культурою загалом. Ці складові світобачення набувають в поезіях символічного звучання, розподіляючи життя для нього на світ і темряву, на спокій і боротьбу, рідне й чуже, на відчуття теплих спогадів минулого та повної безвиході сьогодення й майбутнього. Така дихотомічна система, чітко представлена в художньому ідіолекті поета, виражає його модель світу 3 усім комплексом морально-етичних цінностей, що значною мірою орієнтований не тільки на час життя покоління автора, а й на сучасність i переживання наступних поколінь українців і виходить за межі суто національних проблем, набуваючи загальнолюдського звучання.

Мета дослідження полягає в тому, щоб з'ясувати сутність зіставлюваних понять у порівняннях В. Стуса як складових індивідуально-авторської поетичної картини світу. Для досягнення зазначеної мети було визначено такі завдання: 1) описати порівняння; 2) визначити в ілюзорному світі поета місце людини в розкритті філософських задумів; 3) 3'ясувати закодований зміст культурологічних символів.

Поетична збірка В. Стуса «Палімпсести» містить як традиційні, так і приховані порівняння. Закодований символ приховується в самій назві. Палімпсести в європейській культурі відомі протягом усієї християнської культурної традиції майже 3 VII століття. Рідше вони спостерігаються і в нашій історії. Це 
пергаментні рукописи, які наносилися на змитий, але до кінця не знищений текст. Сучасні технології дозволяють за допомогою ультрафіолетових променів прочитати таємні приховані послання, розкриваючи таємниці минувшини. Палімпсест нагадує славнозвісну думку про те, що рукописи не горять, що пам'ять народу зберігається й передається через віки, що думки та почуття самого автора продовжують національні філософські константи i не можуть бути знищені ніким.

Найбільш значуще поняття для поета - Україна, що порівнюється з лебединею, славою (Україна, Лебединя, Слава за сином назирає з-під руки (с. 82). Лебідь для слов'ян є символічною птицею, що уособлює сонце, вірність, духовну чистоту, благородство, мудрість. Це священний птах життя. Однією 3 засновниць Києва була жінка на ім'я Либідь. Від неї йдуть витоки морально-етичних переконань народу та слави, започаткованої в Київській Русі. 3 лебединею порівнюється звичайна жінка-мати (Мов лебединя, розкрила тонкоголосі дві руки, збілілі губи притулила мені до змерзлої щзоки (с. 101), з голубинею, що символізує мир, щастя, кохання і підносить до вершин чоловіка, кохана жінка, дружина (Мені була ти [кохана] голубинею, щзо розкривала два крила, і мужем, хлопчиком, дитиною мене до неба вознесла (с. 86), із зигзицею, що $є$ символом скорботи та вдовування, - жінка-сестра, яка тужить за братом (Рідна сестра, як зігзиця, б'ється об мури грудьми (с. 86). Безумовно, поетичне мислення автора пов'язане з тими давніми поетичними обрисами жінок-берегинь епохи раннього середньовіччя, які, звертаючись до сил природи, просили захисту для своїх рідних чоловіків. I таким палімпсестом, що не змивається 3 національної пам'яті, на нашу думку, є «Слово про похід Ігоря», де Ярославна плаче на забралі рано-вранці, вдивляючись в небо, соболиним рукавом бажаючи омити обличчя свого коханого, захисника і страдника рідної землі (А біля мене білим соболем тремтить коханої рукав (с. 86). Руки жінок, як два крила птаха, захищають від бід і уможливлюють 
високий злет. I навіть якщо вже нічого не буде в житті, крім високого неба, ці жінки залишаються назавжди, це те, що ніхто не може відібрати (Прикрийся обрію габою, об розпач кулаки оббий $i$ верне образ голубий дружниою ачи сестрою (с. 83). Кохана жінка схожа на кущ бузку (Кохана - ніби кущ бузку, обтяжений 3 задуми й тимі... (с. 106). У поетичному мовленні В. Стуса трапляються порівняння коханої дружини з птахом (I mu-наче птаха - над нашим, над спільним, понад світовим безголів'ям (с. 106); I тінь твоя, тінь проліта - схарапудженим птахом (c. 107); огненним стовпом (Неначе стовп огненний, мене ти з себе викликаєм (с. 108); дітей - 3 птахами (Син - ще малий вигулькував, як птах, мала дочка - живіша од живої - як перепілка, з-за трави густої скидалася... (с. 125).

Ліричний герой як син своєї матері та захисник власної родини навіки честю поєднаний з батьківщиною (Як син, тобі доземно уклонюсь $i$ чесно гляну в чесні твої вічі $i$ в смерть із рідним краєм поріднюсь (с. 99). У контексті віковічних цінностей для автора постає син як зоря, що 3 дохристиянських часів сприймалася як нове життя, воскресіння, відродження, тепло i весна, а за християнською релігійною традицією, - Віфлеємською провісницею нових часів вселюдської любові (I світишся [син], мов зірка, з глибини узвишшя наднебесного (с. 95). Рідні обличчя, збережені в глибинах свідомості людини назавжди, як лики святих, не дають впасти у відчай (...скільки тих облич довкола виду твого, ніби німби... (с. 87). Спогади наповнюють душу, як живильною водою (Душа ласкава, наче озеро, $і$ трохи синім віддає (c. 86). Простір рідної землі нагадує скалок щастя (Нерозпізнане місто дороге відкрилося колючим скалком щастя (с. 97), а Київ давню вимерлу тварину тура, ярого, хороброго, мужнього, сміливого, який не кориться ворогу, не може змиритися з полоном, як і ті давні київські князі, що попри всі перепони піднімаються на боротьбу (Дивись, дивись - за муром цим рудим, за другим, n'ятим, може, й сотимуром дрімучий Київ - здибився буй-туром, 
лукавим косить оком і незлим (с. 97).

Така парадигма цінностей протиставляється страшним реаліям сучасного життя України, коли ії сини полонені, а рідний край став вогняною нивою, нестерпною рідною чужиною (майже як у Т. Шевченка: Малого сліду не покину На нашій славній Украӥні, На нашій - не свойй землі, погаром раю, храмом, зазнаним скверни, царством німоти (А рідна нива, як вогонь, горіла і чорні викидала колоски! (с. 84); Яка нестерпна рідна чужина, цей погар раю, храм, зазнаний скверни! (с. 85); ...рідний край - то царство німоти $\quad$ (с. 85). Щасливе київське життя-щастя залишилося у спогадах і бачиться тільки через квадрати гратчастих вікон (Київ - за тратами. Київ - весь у квадраті вікна (с. 86). Утрата щастя нагадує пекельний вогонь смертельної хвороби i усвідомлення того, що це назавжди (Мов на антоновім огні, не чув нічого я, не бачив. В останньому зусиллі зміг збагнути: все, тебе я втрачу, ось тільки виведуть за ріг... (с. 101).

Поневолена, навіжена, оскаженіла душа поета-страдника опинилася в нових реаліях:

- у духовному та фізичному вакуумі, у порожнечі німоти, піщаній імлі, що нагадують смерть та мертвий пісок (У німій, ніби смерть, порожнечі свічад пересохла імла шебершить, мов пісок (c. 86);

- у темряві вечора - зламаній віті життя, яке розділене на «до» $\mathrm{i}$ «після» (Гойдається вечора зламана віть, неначе розбратаний сам із собою (с. 80); Гойдається вечора зламана віть туга, наче слива, рудою налита (с. 80); Гойдається вечора зламана віть, як костур сліпого, щцо тичеться в простір осінньої невіді (с. 80);

- у крихкій кришталевій ночі (Нiч зсідається, наче кришталь (с. 87) за зведеними невблаганними мурами неволі, що стали зашморгом, уособленням безвиході із ситуації, коли тебе примусово відірвали від батьківщини, сім'ї, всього того, що дороге серцю і без чого життя втрачає сенс (Нас порізнили мури, як 
статут (с. 96); Та мури, мов із мертвих всталі, похмуро мовили: Чекай, ще обрадіє із печалі твій обоюдожалий край (с. 89).

Тюрма асоціюється автором із загальнонаціональним символом біди - совою, яка, на народними повір'ями, $\epsilon$ передвісницею неминучої біди, горя, страшних і непередбачуваних поворотів долі (Глипає оком в 'язниця, наче сова із пітьми (с. 86). Перебування у стані духовного сну, здається, назавжди відділяє від суспільства та активного життя, як люті змії, обвивають тіло і розум (Тут сни долають товщу забуття $і$ згадкою лютуються, як змії...(с. 96). Вимушена бездіяльність, втрачена свобода нагадує встромлений і перевернутий ніж марних прокльонів у понівеченій відкритій душі ( прокльон і повертається в душі розверстій (с. 96).

Залишається тільки пам'ять серця як зустріч, побачення 3 минулим (...сериее оговтати, добігти до пам'яті, немов на побачення - год $i$ (с. 87). І спогади надають сили протистояти долі, не підкоритися обставинам, залишитися незламним, відчувати себе хоч і клітці, зате левом, царем духу, який опинився ув'язненим, тому що на волі його бояться через те, що світ може перевернути (Та погляд застує імла I ти, мов лев, у цій оборі, де стільки кроків в коридорі, - аж світ зайшовся дубала! (с. 83). I знову в асоціаціях з'являється улюблений в Україні народний символ сосни, якою поет позиціонує внутрішній стрижень українського духу, власну незламність, омріяну висоту (Кругом - мериі. I їхні сни стримлять, як сосни, сторч (с. 92). Сосна виростає серед темряви ночі, як омріяні щогла і вітрило казкового корабля на великій воді (Сосна пливе із ночі $i$ росте, як полохке вітрило всечекання (с. 85); Сосна... грудей торкнулась, як вода - весла, і уст - слова (с. 84); Сосна із ночі випливла, мов щцола...(с. 85).

Окреслений тюремними мурами світ чорний, страшний, ворожий і завмерлий (Світ повен сподівань, мов став, мщо ні хлюпнеться (с. 81); Цей став повісплений, осінній, чорний став, як антрацит видінь і кремінь крику, вилискує Лючипера очима 
(с. 82); Всесвіт кружляє, як птах, споквола (с. 143). Усе, що тепер залишилося для спостереження - це:

- скляний та гіркий північний обрій (Як спирту штоф, стоїть осклілий обрій (с. 84); Цей обрій-наче чорний креш гіркої гіркоти (с. 124); Обрій-мов гайворон (с. 143);

- самотні світання (...світання просториться в самотині, як світу заступання (с. 88); Світання - мов яйця пташині, кволі, споквола сині, щзо випали з гнізд $і$ щеебечуть $i$ крильцями тріпотять (с. 88);

- біль (Цей біль - як алкоголь агоній, як вимерзлий до хрусту жсаль (с. 124);

- пульсуючий місяць (У небі місящь горовий скидається, як пульс жсивий (с. 92);

- зоря як Матір Божа, яка дає надію на життя (...ота зоря то тільки скалок болю, щц вічністю пройнятий, мов огнем (с. 101); Ота зоря - вістунка твого шляху, хреста $і$ долі - ніби вічна мати, вивищена до неба...(с. 101);

- Бог, відчуття вищої сили у скалках розбитих дзеркал життя, що скріплює віру і дає змогу душі вистояти у страшних випробуваннях (Вона збирає стосики тонкі усі твої розсипані відбитки, мов золоті, з поховань скіфських, злитки на поза всякий час і всі віки (с. 110);

- украдене сонце (Украдене сонце зизить схарапудженим оком, мов кінь навіжений, щзо чує під серием ножа... (с. 99);

- тиша і спокій (Пливе земля. I спокій сподіванний - як тиша тиші. Як кінець кінця (с. 92);

- стіл, вікно і свіча, які і стали світом письменника (I cmiл, $i$ череп, і свіча, що тіні колихає, $і$ те маленьке потерча, що душу звеселяє. Либонь, для тебе не дано вартнішого зазнати за иьього, щзо спішить вікно, як світ, заколисати (с. 88);

- пісня (...і пісня витикається тонка, як віть оливи у долоні Бога (с. 88);

- привиддя (Привиддя постають - спогадані, згорьовані, 
урочі з моїх артерій кров солону точать $і$ як криваві зозулі кують (с. 109).

Слово стає єдиною зброєю, багнетом, кулями $(O$, скільки слів, неначе поторочі! І всі повз мене, ніби кулі, б'ють... (с. 108). Тюремна кімната зіставляється зі скрипочкою (Скрипить, як скрипочка, вона (с. 103); наглядач - із сатаною (...щохвилини в вічко зазирає іскрадлива, як кицька, сатана, мов дірочку під серием назначає (с. 104); язики сторожових псів - $з$ лезами (I білий, мов лезо, язик пса. I плащуі, щзо під місяцем світять (с. 143); сам невільник - із відьмаком (...кажуть спати рано, ото й телющиши очі, як відьмак (с. 143); муругим конем (..блукаю нею, вражий син, неначе кінь муругий... (с. 103).

Попри всі нещастя, випробування поет вірить, що палаючі смолоскипи буремної душі не згаснуть, освітять шлях до здобуття волі Вітчизною (Розкошлані на всіх вітах вагань, як смолоскипи молодого болю, в неволі здобули для себе волю, ногою заступивши смертну грань (с. 121), що його доля стане посестрою щастя (...нам доля вдасться... I, як жсар-птиця, промайне... (с. 121), що необхідно боротися, чіпляючись за найменшу можливість (Чіпляйся за кручу, як терен колючий. Чіпляйся за небо, як яблуні цвіт (с. 132), тому що незламність духу у крові українців, густій та крутій, як сік калини, народнопісенного символу самої України (Застерігає доля нас зрання, щзо калинова кров - така густа, така крута, як кров у наших жилах (с. 147).

Отже, декодування символічного змісту основних архетипів культурологічного контексту творів автора дали змогу виокремити три групи порівнянь: 1) порівняння матері, дружини, сина, України, Києва зі світом незабутніх спогадів про щасливе життя; 2) порівняння в'язниці, мурів, самоти бранця волі, реалій північного краєвиду (Всесвіт, світ, обрій, світання, місяць, сонце, тиша, тюремна кімната тощо) як страшного світу безвиході; 3) порівняння незламності буремної душі зі шляхом до вищої справедливості. 
Виявлено приховані порівняння як у тексті поезій, літературних ремінісценціях, наприклад «Слово про похід Ігоря» та твори Т. Г. Шевченка, так і в назві збірки.

\section{Література}

1. Голоюх Л. В. Порівняння як структурно-стилістичний компонент художнього тексту (на матеріалі сучасної української історичної прози) : автореф. дис. ... канд. філол. наук / Л. В. Голоюх. - К., 1996. - 20 с.

2. Мисик О. А. Порівняння як спосіб пізнання і відтворення дійсності в індивідуально-авторській картині світу І. Калинця / О.А.Мисик // Вісник Харківського ун-ту імені В. Н. Каразіна. - Харків, 2010. - № 910. - С. 678-682.

3. М'яснянкіна Л. І. Порівняння як лінгвістична категорія / Л. І. М'яснянкіна // Українознавець. - Львів, 2006. - Вип.1. - С. 86-92.

4. Ставицька Л. О. «В незнане вгвинчуй мисль, як вихори спіральні...» (Порівняння в поезії М. Бажана...) / Л. О. Ставицька // Культура слова. - К., 1985. - Вип. 29. - С. 31-34.

5. Стус В. Вікна в позапростір / В. Стус. - К., 1992. - 260 с. Стаття надійшла до редакиії 03.02.2018 p. 